\title{
The Effectiveness of Ethnopedagogy-Based Digital Book Processing in Improving Civics Learning Outcomes in Distance Learning
}

\author{
Novita Majid'1), Warman ${ }^{2)}$ \\ 1),2) Mulawarman University, Samarinda, Indonesia \\ ${ }^{1)}$ novita.majid@fkip.unmul.ac.id, ${ }^{2)}$ warrman58@gmail.com
}

\begin{abstract}
Distance learning in the midst of the current pandemic seems to be a challenge for the creativity of educators to find the right way how to continue to deliver learning materials effectively, the use of technology such as digital books as learning media is one of the appropriate and innovative steps so that the expected goals learning can be achieved. This study aims to improve the learning outcomes of class X SMK Negeri 1 Muargkyu on the subject of National Integration in the Unity in Diversity Frame. This study uses a class action research design. Data were collected through observation, self-assessment, peer-to-peer assessment, journals, interviews, and documentation. There are two data analysis, namely qualitative and quantitative data analysis. The corrective action of learning takes place in 2 cycles consisting of planning, action, observation, and reflection activities. During the learning activities, the students actively participate well. Learning activities that involve students starting from previously doing stimuli through ethnopedagogy-based digital books, observations, value clarification, discussions, compiling reports to evaluations. The results showed that it was successful in improving student learning outcomes of class X SMK Negeri 1 Muarkayu. Improved student learning outcomes (KKM) $90 \%$ of the total number of students as a whole.
\end{abstract}

Keyword: E-Book, Learning Outcomes, Ethnopedagogy, Civic Education, Distance Learning

\section{INTRODUCTION}

Currently almost every country in the world is hit by the Covid-19 outbreak. Countries in the world including Indonesia are busy in setting various policies as an effort to break the chain of the spread of COVID-19. One of the government's policies in the field of education is to organize online distance learning which is an appropriate alternative in the teaching and learning process as an anticipatory step against the current pandemic.

The implementation of distance learning provides its own challenges for education actors, such as educators, students, institutions and even provides challenges for the wider community such as parents. Some threats to the online teaching and learning process include (1) Discipline issues, where the teacher lacks full control in the implementation of distance learning due to various limitations, (2) Learning loss, namely the existence of a teacher curtain as a role model for students so that the knowledge transfer process and exemplary values are not conveyed, this also results in disrupted motivation and thinking processes of students in the learning process. Arora \& Srinivasan (Yuliani \& dkk, 2020, p. 82) that: 
Network problems, lack of training, and lack of awareness are stated as the main challenges faced in online learning. Lack of awareness was stated as the most important reason followed by lack of interest and doubt. Lack of presence, lack of personal touch, and lack of interaction due to connectivity issues were found to be significant drawbacks.

Therefore, it is time for the Government and all elements of education in Indonesia to think about how to apply the right way so that they can still deliver learning materials so that they can be accepted easily and well by students so that the dignity of education, namely harmonization between intellectual and character (morals) is achieved, as regulated in Law Number 20 of 2003 in Article 3, namely national education functions to develop capabilities and shape the character and civilization of a dignified nation in the context of educating the nation's life, aiming to develop the potential of students to become human beings who believe and fear God Almighty. Almighty, noble, healthy, knowledgeable, capable, creative, independent, and become a democratic and responsible citizen.

Ethnopedagogy oriented learning is important to implement because Indonesia is a plural country consisting of various ethnic groups and ethnicities which of course have different cultures. Ethnopedagogy explores and empowers the existence of local wisdom in the student's social environment in shaping student character. It also means revitalizing or reviving the spirit of Indonesia's cultural wealth which is spread from Sabang to Merauke so that in turn our education has its own color or identity (Alwasilah \& dkk, 2009 , p. 27). Learning with an ethnopedagogy approach means that learning is carried out by raising local wisdom so that the delivery of material can be conveyed well to students, so that student learning outcomes are expected to increase, and other things can also increase love for the area. However, the ethnopedagogical approach to learning requires appropriate supporting media.

As a distance learning locomotive, the use of technology that has a variety of media can facilitate all needs in the teaching and learning process. This is in line with Tounder which says that digital technology in educational institutions is a means of supporting learning, both as a means of accessing information on learning resources or as a means of supporting learning activities and relating to assignments (Majid, 2019, p. 10). The use of technology in the form of ethnopedagogy-based digital books as a learning medium is one of the innovative steps to improve the quality of education in Indonesia. In the past, we could read books in the form of sheets of paper arranged in such a way that they could be read by the public. However, now along with the progress of the times, books are not only in the form of paper but can be in digital form that can be stored in smartphones. This activity is also supported by the increasing number of digital books that can be downloaded for free via mobile phones. 
Based on various problems in the field and studies of previous studies. Thus, the author raises research on "The Effectiveness of Ethnopedagogy-Based Digital Book Processing in Improving Civic Education Learning Outcomes in Distance Learning in the Coastal Area of Kutai Kartanegara Regency."

\section{METHOD}

This research was conducted in class X SMK Negeri 1 Marangkayu. This school is located in Marangkau District, Kutai Kartanegara Regency. Marangkayu District is a coastal area in Kutai Kartanegara Regency, the area is in the middle of the kersik coastal area and the rainbow coastal area of Muara Badak District which is famous for its wealth of local wisdom. The subjects of this study were 32 students of class X, Department of TKJ 1, SMK Negeri 1 Marangkayu. The 32 students consisted of 20 female students and 12 male students.

There are two data analysis used in this study, namely qualitative and quantitative data analysis, to measure the progress of student learning outcomes. Learning outcomes are the result of an interaction of teaching and learning actions and are usually indicated by the test scores given by the teacher (Nasution, 2008, p. 36). This study uses a class action research design. Action research is a form of self-reflective research that researchers collectively undertake in social situations to improve the reasoning and fairness of their educational and social applications and their understanding of these applications and of the situations in which these practices are carried out. Thus, classroom action research is a type of research that describes both the process and results of doing CAR in the classroom to improve the quality of learning (Arikunto, Suharjono, \& Supardi, 2021, p. 4)

The advantages of this study include, the teacher does not have to leave his workplace, the teacher can feel the results of the planned actions, if the treatment is carried out on the respondents, they can feel the results of the research treatment (Syamsuddin \& Damaianti, 2006: 194). Therefore, in this study, researchers were assisted by research members who played dual roles as teachers at the school by carrying out corrective actions for learning to be analyzed later.

In this study, the improvement of learning carried out is divided into 3, namely: Pre-cycle, cycle I, and cycle II. In cycle I and cycle II, the cycle consists of 4 stages, namely: planning, action, observation and reflection. Data were collected through teacher observation, self-assessment, peer-to-peer assessment, interviews, tests (evaluations), and documentation. Observation, selfassessment, assessment between friends are used to observe the activities of students during learning. 


\section{RESULT AND DISCUSSION}

\section{Research Result}

Based on the observations that have been made to teachers, students, and the learning process in the subjects of Civic Education class X, it can be seen that Civic Education learning is still done conventionally online. This can be seen from the way the teacher teaches. The way teachers teach is still using conventional methods, where teachers use the lecture method during learning. The teacher does not maximize the media that supports the delivery of learning materials so that learning becomes monotonous when students look bored following the lesson, even $25 \%$ of students do not activate the video camera of the zoom meeting application and $50 \%$ of students are unable to mention things that are examples of Indonesian national identity. The characteristics of nationalism are divided into (1) having a sense of love for the homeland; (2) proud to be part of Indonesia; (3) placing group interests over individual interests; and (4) recognize and value diversity. In this case, knowledge and understanding of National Identity is described in the characteristics of nationalism (Rosita, Japar, \& Timoera, 2013, p. 11) . Then, from the results of observations, the researchers distributed questionnaires as initial conditions in class X TKJ 1. Below are the results of the initial conditions of learning outcomes data owned by students:

Table 1. Data on Civic Education Learning Outcomes for Class X TKJ 1 (Pre-Cycle)

\begin{tabular}{|c|c|c|c|c|c|c|c|c|c|c|c|c|c|c|c|}
\hline \multirow{2}{*}{$\frac{\text { No }}{1 .}$} & \multirow{2}{*}{\multicolumn{2}{|c|}{$\frac{\text { Name }}{A} \frac{\text { Score }}{72}$}} & \multirow{2}{*}{$\begin{array}{c}\text { Desc } \\
\text { BT }\end{array}$} & \multirow{2}{*}{$\begin{array}{c}\text { No } \\
9 .\end{array}$} & \multicolumn{3}{|c|}{ Name Score Desc } & \multirow{2}{*}{$\begin{array}{l}\text { No } \\
17 .\end{array}$} & \multicolumn{3}{|c|}{ Name Score Desc } & \multirow{2}{*}{$\begin{array}{l}\text { No } \\
25 .\end{array}$} & \multicolumn{3}{|c|}{ Name Score Desc } \\
\hline & & & & & I & 74 & BT & & $\mathrm{Q}$ & 72 & BT & & Y & 70 & BT \\
\hline 2. & B & 72 & BT & 10. & $\mathrm{~J}$ & 97 & $\mathrm{~T}$ & 18. & $\mathrm{R}$ & 74 & BT & 26. & $\mathrm{Z}$ & 70 & $\mathrm{BT}$ \\
\hline 3. & $\mathrm{C}$ & 74 & BT & 11. & $\mathrm{~K}$ & 72 & BT & 19. & $\mathrm{~S}$ & 70 & BT & 27. & AA & 80 & $\mathrm{~T}$ \\
\hline 4. & $\mathrm{D}$ & 74 & BT & 12. & $\mathrm{~L}$ & 60 & BT & 20. & $\mathrm{~T}$ & 78 & $\mathrm{~T}$ & 28. & $\mathrm{AB}$ & 65 & $\mathrm{BT}$ \\
\hline 5. & $\mathrm{E}$ & 62 & BT & 13. & M & 63 & BT & 21. & UU & 78 & $\mathrm{~T}$ & 29. & $\mathrm{AC}$ & 70 & $\mathrm{BT}$ \\
\hline 6. & $\mathrm{~F}$ & 69 & BT & 14. & $\mathrm{~N}$ & 80 & $\mathrm{~T}$ & 22 & V & 80 & $\mathrm{~T}$ & 30. & $\mathrm{AD}$ & 65 & BT \\
\hline 7. & G & 77 & $\mathrm{~T}$ & 15. & 0 & 85 & $\mathrm{~T}$ & 23. & W & 72 & $\mathrm{BT}$ & 31. & $\mathrm{AE}$ & 65 & $\mathrm{BT}$ \\
\hline 8. & $\mathrm{H}$ & 62 & BT & 16. & $\mathrm{P}$ & 69 & BT & 24. & $\mathrm{X}$ & 72 & BT & 32. & $\mathrm{AF}$ & 72 & $\mathrm{BT}$ \\
\hline \multicolumn{8}{|c|}{$\begin{array}{l}\text { Average } \\
\text { Value }\end{array}$} & \multicolumn{4}{|c|}{72,34} & & & & \\
\hline
\end{tabular}

\section{Information:}

BT = Not Completed according to Minimum Completeness Criteria (KKM), value $<75$

$\mathrm{T}=$ Completed according to Minimum Completeness Criteria (KKM), value $\geq 75$

Based on table 1, it can be determined that there are 8 students or $25 \%$ of students who complete the minimum completeness criteria. This learning outcomes data becomes the basic capital for researchers to take corrective actions in learning so that student learning outcomes increase. 


\section{Cycle 1}

This research was conducted on 02 and 05 August 2021. The first cycle of data collection was carried out in two meetings with a time of $3 \mathrm{JP}$. The data obtained from the first cycle consisted of four stages, namely: planning, implementation, observation, and reflection.

Based on the observations of the first meeting, it can be seen that the learning took place quite effectively. The teacher is very good at opening the lesson, especially when giving shouts to encourage the class. The process of opening the lesson was also carried out by singing the song "Indonesia Raya and Burung Enggang" and mentioning Indonesia's national identity. This is certainly very relevant to learning. However, the teacher did not explain the method or steps of work or activities to be carried out, so that students also seemed less familiar with the media used so that their use was not so optimal. Moreover, student learning activities have not yet grown. Students are still passive in learning. More than half of the students did not dare to express opinions or answer questions. Overall, the research went according to the lesson plan.

Then, based on the results of the observation of meeting 2 in cycle I, it can be explained that the learning activities are running according to the lesson plan that has been made, but the evaluation is not fully appropriate. Student learning activities have begun to grow, which is marked by actively seeking information in ethnopedagogy-based digital books directed by teachers. Students look more conducive when divided into smaller groups. However, there are shortcomings, namely in the delivery of material that is integrated into local local wisdom by the teacher and the previous detailed information provided on student reading literature through digital books, resulting in less learning time.

Thus, the implementation of the first cycle has been carried out in accordance with the learning implementation plan. At every opening at every meeting, students are so excited to sing the national anthem. The first and second meetings were held on 02 and 05 August 2021. The material presented at the first meeting was National Integration within the Unity in Diversity Frame. The learning process was quite effective, but more than half of the students did not dare to express opinions or answer questions. Students actively seek information in ethnopedagogybased digital books directed by the teacher according to the subject matter provided. However, there are still some details that are not paid attention to. The following is the result of cycle I:

Table 2. Data on Civic Education Learning Outcomes Class X TKJ 1 (Cycle 1)

\begin{tabular}{|c|c|c|c|c|c|c|c|c|c|c|c|c|c|c|c|}
\hline No & Name & Score & Desc & No & Name & Score & Desc & No & Name & Score & Desc & No & Name & Score & Desc \\
\hline 1. & A & 78 & $\mathrm{~T}$ & 9. & I & 85 & $\mathrm{~T}$ & $\overline{17 .}$ & $Q$ & 72 & BT & 25. & $Y$ & 85 & $\mathrm{~T}$ \\
\hline 2. & B & 75 & $\mathrm{~T}$ & 10. & $\mathrm{~J}$ & 98 & $\mathrm{~T}$ & 18. & $\mathrm{R}$ & 80 & $\mathrm{~T}$ & 26. & $\mathrm{Z}$ & 70 & $\mathrm{BT}$ \\
\hline 3. & $\mathrm{C}$ & 78 & $\mathrm{~T}$ & 11. & K & 80 & $\mathrm{~T}$ & 19. & S & 70 & BT & 27. & $\mathrm{AA}$ & 80 & $\mathrm{~T}$ \\
\hline 4. & D & 78 & $\mathrm{~T}$ & 12. & L & 60 & BT & 20. & $\mathrm{~T}$ & 80 & $\mathrm{~T}$ & 28. & $\mathrm{AB}$ & 65 & BT \\
\hline 5. & E & 75 & $\mathrm{~T}$ & 13. & M & 63 & BT & 21. & UU & 80 & $\mathrm{~T}$ & 29. & $\mathrm{AC}$ & 70 & BT \\
\hline 6. & $\mathrm{~F}$ & 75 & $\mathrm{~T}$ & 14. & $\mathrm{~N}$ & 80 & $\mathrm{~T}$ & 22. & V & 88 & $\mathrm{~T}$ & 30. & $\mathrm{AD}$ & 65 & BT \\
\hline 7. & G & 77 & $\mathrm{~T}$ & 15. & 0 & 85 & $\mathrm{~T}$ & 23. & W & 88 & $\mathrm{~T}$ & 31. & $\mathrm{AE}$ & 65 & BT \\
\hline 8. & $\mathrm{H}$ & 62 & BT & 16. & $\mathrm{P}$ & 69 & BT & 24. & $\mathrm{X}$ & 85 & $\mathrm{~T}$ & 32. & $\mathrm{AF}$ & 80 & $\mathrm{~T}$ \\
\hline
\end{tabular}

Avg. Score 76,28 
Information:

BT = Not Completed according to Minimum Completeness Criteria (KKM), value $<75$

$\mathrm{T}=$ Completed according to Minimum Completeness Criteria (KKM), value $\geq 75$

Based on table 2 there are 11 students who have not completed, namely students whose scores are below 75. Meanwhile, 21 students who have completed or it is concluded that there are $65 \%$ who have completed according to the minimum completeness criteria (KKM).

If it is calculated from the learning outcomes, then this learning improvement action has also been successful, although not optimal. Before the first cycle, only 8 students or $20 \%$ completed according to the minimum completeness criteria, after the first cycle, 21 students or $65 \%$ completed. Based on these results, it can be concluded that the corrective actions taken have not been optimal, because $75 \%$ of students have not achieved the minimum completeness criteria. Therefore, corrective action needs to be taken in the next cycle.

\section{Cycle 2}

This research was conducted on 18 and 25 August 2015. The data collection cycle II was carried out in two meetings with a time of 6 meeting hours or 6 JP. The data obtained from cycle II consisted of four stages, namely: planning, implementation, observation, and reflection.

The implementation of cycle II was carried out in one meeting. Each meeting is held for 2 hours of lessons ( $3 \times 45$ minutes). The meeting was held on August 23, 2015 with material on understanding the integrity of the Unitary State of the Republic of Indonesia and the provinces in Indonesia and their culture. Two days after the end of cycle II, students were distributed attitude scale questionnaires to work on.

Based on the observation that the learning process runs according to the learning implementation plan. Class mastery is very good, student enthusiasm is also very high during learning. Students watch videos about cultural diversity, five things that are interesting and claimed by other countries. The video is used as a problem given to students, to be discussed.

The implementation of the second cycle has been carried out in accordance with the learning implementation plan (RPP). The first meeting was held on August 23, 2021 with the material understanding the Integrity of the Unitary State of the Republic of Indonesia (NKRI) and the Provinces in Indonesia and their Culture. The learning process took place effectively, then students were very enthusiastic about using ethnopedagogical-based digital books according to the teacher's direction to find information related to the material and problems given. In addition, students were also very enthusiastic when they saw video shows about the diversity of Indonesian culture and how to maintain the integrity of the Unitary Republic of Indonesia. The following are the results of cycle II: 
Table 3. Data on Civic Education Learning Outcomes Class X TKJ 1 (Cycle 2)

\begin{tabular}{|c|c|c|c|c|c|c|c|c|c|c|c|c|c|c|}
\hline No Nama & \multirow{2}{*}{$\frac{\text { Nilai }}{90}$} & \multirow{2}{*}{$\begin{array}{c}\text { Ket } \\
\mathrm{T}\end{array}$} & \multicolumn{4}{|c|}{ No Nama Nilai Ket } & \multicolumn{4}{|c|}{ No Nama Nilai Ket } & \multicolumn{4}{|c|}{ No Nama Nilai Ket } \\
\hline A & & & 9. & I & 93 & $\mathrm{~T}$ & 17. & $Q$ & 87 & $T$ & 25. & $\mathrm{Y}$ & 100 & $\mathrm{~T}$ \\
\hline 2. & 96 & $\mathrm{~T}$ & 10. & $\mathrm{~J}$ & 100 & $\mathrm{~T}$ & 18. & $\mathrm{R}$ & 85 & $\mathrm{~T}$ & 26. & $\mathrm{Z}$ & 90 & $\mathrm{~T}$ \\
\hline $\mathrm{C}$ & 96 & $\mathrm{~T}$ & 11. & K & 90 & $\mathrm{~T}$ & 19. & S & 78 & $\mathrm{~T}$ & 27. & $\mathrm{AA}$ & 90 & $\mathrm{~T}$ \\
\hline 4. & 90 & $\mathrm{~T}$ & 12. & $\mathrm{~L}$ & 69 & BT & 20. & $\mathrm{~T}$ & 98 & $\mathrm{~T}$ & 28. & $\mathrm{AB}$ & 90 & $\mathrm{~T}$ \\
\hline 5. & 90 & $\mathrm{~T}$ & 13. & $\mathrm{M}$ & 70 & BT & 21. & UU & 98 & $\mathrm{~T}$ & 29. & $\mathrm{AC}$ & 90 & $\mathrm{~T}$ \\
\hline 6. & 85 & $\mathrm{~T}$ & 14. & $\mathrm{~N}$ & 98 & $\mathrm{~T}$ & 22. & V & 100 & $\mathrm{~T}$ & 30. & $\mathrm{AD}$ & 68 & $\mathrm{BT}$ \\
\hline 7. & 93 & $\mathrm{~T}$ & 15. & 0 & 100 & $\mathrm{~T}$ & 23. & W & 100 & $\mathrm{~T}$ & 31. & $\mathrm{AE}$ & 68 & BT \\
\hline 8. $\mathrm{H}$ & 82 & $\mathrm{~T}$ & 16. & $\mathrm{P}$ & 85 & $\mathrm{~T}$ & 24. & $\mathrm{X}$ & 98 & $\mathrm{~T}$ & 32. & $\mathrm{AF}$ & 88 & $\mathrm{~T}$ \\
\hline $\begin{array}{l}\text { Avg. } \\
\text { Score }\end{array}$ & & & & & & & & & & & & & & \\
\hline
\end{tabular}

BT = Not Completed according to Minimum Completeness Criteria (KKM), value $<75$

$\mathrm{T}=$ Completed according to Minimum Completeness Criteria (KKM), value $\geq 75$

\section{Discussion}

This classroom action research uses a Problem Based Learning model with an ethnopedagogical learning approach based on digital books to improve student learning outcomes. The measuring instrument used in this research is Cycle I research carried out in two meetings. The meeting was held on 02 and 05 August 2021. The material presented at the first meeting was National Integration within the Bhinneka Tunggal Ika Frame, with Competency Standards 1. Understanding, applying, and analyzing factual, conceptual, procedural, and metacognitive knowledge based on their curiosity about science, technology, art, culture, and humanities with insight into humanity, nationality, state, and civilization related to the causes of phenomena and events, as well as applying procedural knowledge in specific fields of study according to their talents and interests to solve problems. Meanwhile, the Basic Competence is 1.7 Being grateful for the values that make up the commitment to national integration within the framework of Bhinneka Tunggal Ika as a form of gratitude to God Almighty.

The learning process is quite effective. The students were very excited to sing the national anthem and the folk anthem of East Kalimantan at the opening time. However, students are still not accustomed to using the Problem Based Learning model and ethnopedagogy-based digital book learning media according to the directions given. Then, more than half of the students did not dare to ask opinions or answer questions.

If it is calculated from the learning outcomes, then this learning improvement action has also been successful, although not optimal. Before the first cycle, only 8 students or $20 \%$ completed according to the minimum completeness criteria (KKM), after the first cycle, 21 students or $65 \%$ completed. Based on these results, it can be concluded that the corrective actions taken have not been optimal, because $75 \%$ of students have not achieved the minimum completeness criteria. Therefore, corrective action needs to be taken in the next cycle. 
Although it still needs improvement, this cycle has shown several advantages, including:

1) Improvement of critical thinking skills and learning outcomes;

2) The attention span of students during learning is longer;

3) The use of technology is an element of surprise that students like

4) In addition to having advantages,

In this cycle also has shortcomings that must be corrected in the next cycle, namely there are still students who are less active in following the learning process well and are noisy alone with their friends. After analyzing the unsuccessful cycle I, the researcher decided to take corrective actions for learning in Cycle II.

The second cycle of research was carried out on August 26, 2021 with the material Understanding the Integrity of the Unitary State of the Republic of Indonesia and the Provinces in Indonesia and Their Culture. Cycle II uses Basic Competencies 1.2 Explains the importance of the integrity of the Unitary State of the Republic of Indonesia. The learning process is effective. Students are more active in seeking information related to the material and directions given by the teacher using ethnopedagogy-based digital books. Students were very enthusiastic when they saw a video showing how to maintain the integrity of the Unitary State of the Republic of Indonesia and the diversity of Indonesian culture. The Problem Based Learning model is more effective when it is collaborated with interesting media such as ethnopedagogy-based digital books which strongly support online learning because it is digital and appropriate to the material provided.

The implementation of the research carried out was carried out in accordance with the RPP and what had been planned. The purpose of this research is to improve the attitude/character of nationalism and improve learning outcomes of Civics for class X TKJ 1 SMK Negeri 1 Marangkayu. The table summarizing aspects of research achievements that have been compiled from the initial conditions, cycle I, and cycle II after implementation can be seen in table 4 below:

The results of implementing Civics learning with an ethnopedagogical approach based on digital books can be seen in the table below:

Table 4. Summary of Student Learning Outcomes for Class X TKJ 1

\begin{tabular}{cccccc}
\hline \multicolumn{2}{c}{ Kondisi Awal } & \multicolumn{2}{c}{ Siklus I } & \multicolumn{2}{c}{ Siklus II } \\
\hline Persentase & Nilai & Persentase & Nilai & Persentase & Nilai \\
\hline $\mathbf{2 5 \%}$ & $\mathbf{7 2 , 3 4}$ & $\mathbf{6 5 \%}$ & $\mathbf{7 6 , 2 8}$ & $\mathbf{9 0 \%}$ & $\mathbf{8 9 , 2 1}$ \\
\hline
\end{tabular}

Based on the table above, it can be seen that the percentage of student learning outcomes in the initial conditions was only $25 \%$, in the first cycle it rose to $65 \%$ and in the second cycle it was $90 \%$. Meanwhile, an increase can also be seen from the average score of students. The 
average score of students in the initial conditions was 72.34 , the first cycle was 76.28 , and in the second cycle it rose to 89.21 .

(Winkel, 2009, p. 24) mentions the factors that affect the process and learning outcomes which are classified into 4 groups, namely:

1) The group of students includes the level of intelligence, physical condition, and learning motivation;

2) The teacher group includes learning techniques, teaching methods, and lesson materials;

3) Schools as institutions include learning facilities and infrastructure and school leaders;

4) Situational factors include the state of the school, the location of teaching and learning activities, and climate/weather.

In this study, the success of students in participating in the learning program is seen from the achievement or improvement of student learning outcomes. Thus it can be explained that learning achievement is the level of ability possessed by students in accepting, rejecting and assessing the information obtained in the teaching and learning process. Student learning outcomes can be known after an evaluation is held. The results of the evaluation can show the high or low learning achievement of students.

Thus, based on observations and student learning outcomes after working on evaluation questions, it can be concluded that there is an increase in student learning outcomes. This proves that the actions taken by applying a digital book-based ethnopedagogical learning approach to civic education subjects on special materials for National Integration within the Unity in Diversity Frame are successful. Thus, it is not continued in the next cycle.

These results further strengthen that basically ethnopedagogy as stated by (Yunus, 2014, p. 146) has the following objectives: (1) exploring the best values and experiences in the implementation of local culture-based education; (2) explore core values as the sociocultural foundation for national education; and (3) elaborating the patterned behavior system as a socio-cultural context for national education, which has indeed been proven to improve every cognitive, affective, and conative aspect, as well as the overall attitude of nationalism.

Teaching and learning activities (KBM) by applying an ethnopedagogical approach based on digital books that have been carried out by students in cycle II are as follows:

1) Students listen to the teacher's explanation of the learning activities to be carried out.

2) Students sing one of the national and regional songs of East Kalimantan.

3) Students listen to the teacher's explanation of the material on National Integration in the Bhinneka Tunggal Ika Frame.

4) Students are formed into groups to discuss the material/problems that have been distributed. 
5) Students use ethnopedagogy-based digital books as reading literature in accordance with teaching materials directed by the teacher.

6) Students work on evaluation questions.

7) Students summarize the material that has been studied.

8) Students do reflection.

\section{CONCLUSION}

This classroom action research was carried out in two cycles aimed at improving student learning outcomes in civic education learning with an ethnopedagogy approach based on digital books. Based on the research that has been done, by conducting civic education learning using an ethnopedagogical approach based on digital books on the National Integration material in the Unity in Diversity Frame, it was found that there was an increase in the percentage of student learning outcomes, in the initial condition it was only $25 \%$, in the first cycle it rose to $65 \%$. and in the second cycle by $90 \%$. Meanwhile, an increase can also be seen from the average score of students. The average score of students in the initial conditions was 72.34 , the first cycle was 76.28 , and in the second cycle it rose to 89.21 .

\section{REFERENCES}

Alwasilah, A. C., \& dkk. (2009). Etnopedagogi Landasan Praktek Pendidikan dan Pendidikan Guru. Bandung: PT Kiblat Buku Utama.

Arikunto, S., Suharjono, \& Supardi. (2021). Penelitian Tindakan Kelas. Jakarta: PT Bumi Aksara.

Arora, A. K., \& Srinivasan, R. (2020). Impact of pandemic COVID-19 on the teaching - learning process: A study of higher education teachers. Parabadhan: Indian Journal of Management, $13(4)$.

Kemendikbud. (2017). Panduan Penilaian oleh Pendidik dan Satuan Pendidikan untuk Sekolah Menengah Atas. Jakarta: Direktorat Jenderal Pendidikan Dasar dan Menengah.

Majid, N. (2019). Penguatan Karakter melalui Local Wisdom sebagai Budaya Kewarganegaraan. Takalar: Yayasan Ahmar Cendekia Indonesia.

Nasional, D. P. (2003). Undang-Undang Nomor 20 Tahun 2003 Tentang Sistem Pendidikan Nasional. Jakarta: Depdiknas.

Nasution. (2008). Peranan Teknologi Pendidikan Dalam Meningkatkan Kualitas Pembelajaran. Jakarta: Bumi Aksara.

Rosita, Japar, M., \& Timoera, D. A. (2013). Hubungan Pemahaman Bela Negara dengan Nasionalisme Siswa di SMP 3 Tambun. Jurnal PPKN Online, 1-9.

Syamsuddin, \& Damayanti. (2006). Metode Penelitian Pendidikan Bahasa. Bandung: Remaja Rosdakarya. 
Winkel, W. S. (2009). Psikologi Pengajaran. Jakarta: Gramedia.

Yuliani, M., \& dkk. (2020). Pembelajaran Daring untuk Pendidikan: Teori dan Penerapan. Medan: Yayasan Kita Menulis.

Yunus, R. (2014). Nilai-nilai Kearifan Lokal (Local Genius) Sebagai Penguat Karakter Bangsa: Studi Empiris Tentang Huyula. Yogyakarta: Deepublish. 